\title{
MENINGKATKAN SIKAP ENTERPRENEURSHIP SISWA MELALUI PENERAPAN MODEL PEMBELAJARAN TEACHING FACTORY 6 LANGKAH
}

\author{
Dani Setyawan ${ }^{1}$, Dadang Hidayat ${ }^{2}$, Amay Suherman ${ }^{3}$ \\ Departemen Pendidikan Teknik Mesin, FPTK UPI \\ Jl. Dr. Setiabudhi No. 207 Bandung 40154 \\ danisetyawanbatch3@gmail.com
}

\begin{abstract}
ABSTRAK
Tujuan penelitian ini adalah untuk meningkatkan sikap entrepreneurship siswa pada kompetensi teknik sepeda motor dengan menerapkan model pembelajaran Teaching Factory 6 Langkah. Metode penelitian yang digunakan adalah metode kuasi eksperimen. Penelitian kuasi eksperimen ini diberikan kepada siswa kelas XI TSM SMK Negeri 1 Majalengka. Pengumpulan data dilakukan dengan menggunakan angket. Hasil dari penelitian ini yaitu lima seri pembelajaran yang telah dilakukan menunjukkan bahwa peningkatan sikap entrepreneurship pada kelas eksperimen lebih besar daripada sikap entrepreneurship pada kelas kontrol. Disimpulkan bahwa penerapan model pembelajaran Teaching Factory 6 Langkah dapat meningkatkan sikap entrepreneurship kelas XI TSM SMK Negeri 1 Majalengka.
\end{abstract}

Kata kunci: teaching factory, sikap wirausaha, kompetensi

\section{PENDAHULUAN}

Perkembangan ilmu pengetahuan dan teknologi di Indonesia saat ini berkembang cukup maju dan pesat. Seiring dengan perkembangan teknologi tersebut, diperlukan adanya peningkatan sumber daya manusia di Indonesia. Pendidikan merupakan salah satu bagian dalam pengembangan sumber daya manusia. Melalui pendidikan seseorang dapat menjadi pribadi yang mandiri dan bertanggung jawab. Menurut UU Republik Indonesia No.20 tahun 2003 tentang sistem pendidikan nasional dalam bab II pasal 3 tentang fungsi dan tujuan pendidikan nasional.

Sekolah Menengah Kejuruan (SMK) saat ini menjadi salah satu bagian penting dalam dunia pendidikan di Indonesia. Sesuai dengan peraturan pemerintah No. 56 Tahun 1998 pada Pasal I Ayat 3 menyatakan bahwa pendidikan menengah kejuruan adalah pendidikan pada jenjang pendidikan menengah yang mengutamakan pengembangan kemampuan siswa untuk melaksanakan pekerjaan tertentu. Menurut data terakhir dari badan pusat statistik Indonesia periode agustus 2012, memaparkan bahwa jumlah pengangguran di Indonesia mencapai 7,2 juta orang. Lulusan SMK menyumbang angka pengangguran mencapai 1.041 .265 orang.

\footnotetext{
${ }^{1}$ Mahasiswa Departemen Pendidikan Teknik Mesin FPTK UPI

${ }^{2}$ Dosen Departemen Pendidikan Teknik Mesin FPTK UPI

${ }^{3}$ Dosen Departemen Pendidikan Teknik Mesin FPTK UPI
} 
Melihat banyaknya lulusan SMK yang tidak bekerja menjadi satu masalah yang cukup penting, karena tidak sesuai dengan tujuan SMK, dimana SMK menyiapkan kemampuan lulusan yang mempunyai keahlian untuk mengerjakan pekerjaan tertentu dan mahir dalam suatu bidang dan siap kerja. Selain tidak adanya kesesuaian antara kebutuhkan pasar kerja dan kualifikasi kompetensi calon tenaga kerja Besarnya penggangguran juga terjadi karena jumlah pencari kerja jauh lebih besar dari kesempatan kerja yang ada (Hendro, 2011). Selain mahir dalam bidang tertentu dan siap kerja, lulusan SMK juga diharapkan dapat mandiri dan menggunakan kemampuan mereka untuk berwirausaha. Seperti yang tercantum di dalam kurikulum SMK dan sesuai dengan amanat Kementerian Pendidikan Nasional melalui renstra tahun 2010-2014, yang menyatakan bahwa seluruh SMK diwajibkan untuk menyediakan layanan pembinaan pengembangan kewirausahaan. Para wirausaha adalah orang-orang yang mempunyai kemampuan melihat dan menilai kesempatan kesempatan bisnis (Meredith, 1992). Mengumpulkan sumbersumber daya yang dibutuhkan guna mengambil keuntungan daripadanya dan mengambil tindakan yang tepat guna memastikan sukses.

Kenyataan yang terjadi di Indonesia tingkat sikap berwirausaha masyarakat masih dikatakan rendah. Jumlah wirausahawan di Indonesia masih kurang, menurut data dari kementrian koperasi dan usaha kecil menengah. Jumlah wirausahawan Indonesia berjumlah $1,26 \%$ dari total penduduk Indonesia. Angka tersebut masih kurang dari ideal sebagai negara berkembang, karena dengan bertambahnya masyarakat untuk berwirausaha dapat mencetak banyak lapangan pekerjaan baru untuk membantu perekonomian bangsa dan mengurangi angka pengangguran. Suatu negara dapat dikatakan makmur apabila minimal memiliki jumlah enterpreneur atau wirausahawan sebanyak dua persen dari jumlah populasi penduduknya (Kartib dan Yuyus, 2010). Kewirausahaan memiliki peranan yang strategis dalam menciptakan pelaku bisnis dan perusahaan yang baru serta membuka lapangan kerja.

Diperlukan suatu perubahan dalam sistem pendidikan di SMK dalam hal model pembelajarannya. Proses pembelajaran yang biasa dilakukan, yang berpusat pada guru dan murid kurang berperan aktif, dinilai kurang optimal untuk dapat meningkatkan sikap berwirausaha siswa SMK. Model pembelajaran yang dapat digunakan adalah model pembelajaran Teaching Factory 6 Langkah (TF-6M). Model pembelajaran ini siswa dapat merasakan suasana industri yang sebenarnya dan mendapatkan pengalaman yang nyata mengenai dunia wirausaha. Hal ini sesuai dengan manajemen dikdasmen yang memproyeksikan SMK lulusannya bisa menciptakan 
lapangan pekerjaan 20\%, mendapat pekerjaan dalam Negeri sebesar $50 \%$ dan mendapat pekerjaan luar negeri sebesar 10\% serta melanjutkan ke perguruan tinggi sebesar 10\% (Hidayat, 2010).

Penerapan model pembelajaran TF-6M, suasana proses pembelajarannya dirancang seperti dalam suasana industri yang nyata. Belajar dari pengalaman nyata diharapkan akan jauh lebih bermakna dan dapat optimal dalam mengembangkan potensi siswa. Diharapkan dapat membentuk sikap berwirausaha bagi setiap siswa. Berkomunikasi dengan konsumen untuk menerima pesanan, menganalisa pesanan, menyatakan kesiapan mengerjakan pesanan, mengerjakan pesanan, melakukan quality control dan menyerahkan pesanan kepada konsumen adalah pembelajaran yang nyata dan sangat baik dalam proses peningkatan sikap atau karakter berwirausaha (Suryana dan Bayu, 2010). Pembelajaran dengan model TF-6M dapat menjadi modal yang sangat baik ketika lulusan SMK nantinya ingin membuka usaha mandiri. Melihat data dari badan pusat statistik Indonesia mengenai pemakai kendaraan bermotor, pada tahun 2011 pengguna kendaraan sepeda motor mencapai 68.839.341. Melihat jumlah yang begitu besar, hal ini dapat menjadi peluang bisnis yang sangat menguntungkan bagi lulusan SMK kompetensi keahlian sepeda motor untuk membuka jasa perawatan kendaraan bermotor.

\section{METODE PENELITIAN}

Adapun desain penelitian dalam penelitian ini adalah Nonequivalent Control Group Design. Dengan desain ini, baik kelompok eksperimental maupun kelompok kontrol dibandingkan, kendati kelompok tersebut dipilih dan ditempatkan tanpa melalui randomisasi.

Metode penelitian yang digunakan dalam penelitian ini adalah metode kuasi eksperimen. Penelitian kuasi eksperimen adalah metode penelitian yang digunakan untuk mencari pengaruh perlakuan tertentu terhadap yang lain dalam kondisi yang terkendalikan. Penelitian kuasi eksperimen dilakukan dengan mengadakan manipulasi terhadap obyek penelitian serta adanya kontrol. Penelitian ini kedua kelompok diberikan perlakuan yang berbeda. Kelompok eksperimen dalam penelitian ini adalah kelompok yang diberikan perlakuan model pembelajaran model TF6M. Sedangkan kelompok kontrol dalam penelitian ini adalah kelompok yang menggunakan model pembelajaran yang biasa dilakukan di SMK Negeri 1 Majalengka. 


\section{HASIL PENELITIAN}

Sebagaimana telah dikemukakan sebelumnya, sikap entrepreneurship dalam hal ini diukur berdasarkan lima indikator, yakni motivasi berprestasi; orientasi ke depan; kepemimpinan wirausaha; jaringan usaha; responsif dan kreatif menghadapi perubahan. Tabel 1, 2 dan 3 menunjukkan persentase ketercapaian skor dari hasil penelitian yang telah dilakukan.

Tabel 1. Rata-rata Persentase Ketercapaian Skor Sikap Entrepreneurship

\begin{tabular}{lcc}
\hline Kelas & & Rata-rata Persentase Ketercapaian Skor \\
\hline Eksperimen & Pretest & $74,06 \%$ \\
& Posttest & $81,53 \%$ \\
Kontrol & Pretest & $73,35 \%$ \\
& Postest & $74,15 \%$ \\
\hline
\end{tabular}

Peningkatan sikap entrepreneurship berdasarkan masing-masing indikator dapat dilihat berdasarkan persentase ketercapaian skor.

Tabel 2. Persentase Ketercapaian Skor Sikap Entrepreneurshipdan N-Gain

\begin{tabular}{lccccc}
\hline \multicolumn{1}{c}{ Indikator } & \multicolumn{5}{c}{ Kelas Eksperimen } \\
\cline { 2 - 6 } & $\begin{array}{c}\text { \% Ketercapaian } \\
\text { skor Pretest } \\
\text { Motivasi }\end{array}$ & $\begin{array}{c}\text { \% Ketercapaian } \\
\text { skor Posttest } \\
\text { berprestasi }\end{array}$ & $\begin{array}{c}\% \\
\text { Peningkatan }\end{array}$ & $N$-Gain & $\begin{array}{c}\text { Kategori } \\
N \text {-Gain }\end{array}$ \\
$\begin{array}{l}\text { Orientasi ke depan } \\
\text { Kepemimpinan } \\
\text { wirausaha }\end{array}$ & $75.24 \%$ & $82.76 \%$ & $7.53 \%$ & 0.30 & Sedang \\
$\begin{array}{l}\text { Jaringan usaha } \\
\begin{array}{l}\text { Responsif dan } \\
\text { kreatif menghadapi } \\
\text { perubahan }\end{array}\end{array}$ & $75.59 \%$ & $80.47 \%$ & $5.82 \%$ & 0.23 & Rendah \\
\hline
\end{tabular}

Tabel 3. Persentase Ketercapaian Skor Sikap Entrepreneurship

\begin{tabular}{|c|c|c|c|c|c|}
\hline \multirow[t]{3}{*}{ Indikator } & \multicolumn{5}{|c|}{ Kelas Kontrol } \\
\hline & $\%$ & $\%$ & $\%$ & $N$-Gain & Kategori \\
\hline & $\begin{array}{c}\text { Ketercapaian } \\
\text { skor Pretest }\end{array}$ & $\begin{array}{l}\text { Ketercapaian } \\
\text { skor Posttest }\end{array}$ & Peningkatan & & $N$-Gain \\
\hline Motivasi berprestasi & $74.67 \%$ & $76.36 \%$ & $1.70 \%$ & 0.07 & Rendah \\
\hline Orientasi ke depan & $74.00 \%$ & $73.45 \%$ & $-0.55 \%$ & -0.02 & Rendah \\
\hline $\begin{array}{l}\text { Kepemimpinan } \\
\text { wirausaha }\end{array}$ & $73.40 \%$ & $73.23 \%$ & $-0.17 \%$ & -0.01 & Rendah \\
\hline Jaringan usaha & $72.65 \%$ & $77.05 \%$ & $4.39 \%$ & 0.16 & Rendah \\
\hline $\begin{array}{l}\text { Responsif dan kreatif } \\
\text { menghadapi } \\
\text { perubahan }\end{array}$ & $72.36 \%$ & $72.69 \%$ & $0.32 \%$ & 0.01 & Rendah \\
\hline
\end{tabular}


Hasil rata-rata $N$-Gain (Gambar 1) dari kelas eksperimen lebih besar daripada rata-rata $N$ Gain kelas kontrol. Hasil rata-rata $N$-Gain kedua kelas berada pada kategori rendah. Melihat hasil perbandingan $\mathrm{N}$-Gain antara kelas eksperimen dan kelas kontrol. Berikut ini adalah sebaran nilai $\mathrm{N}$-Gain yang diperoleh masing-masing siswa pada kelas eksperimen dan kontrol. Pengujian hipotesis dilakukan untuk mengetahui apakah hipotesis yang diajukan dalam penelitian ini diterima atau ditolak.

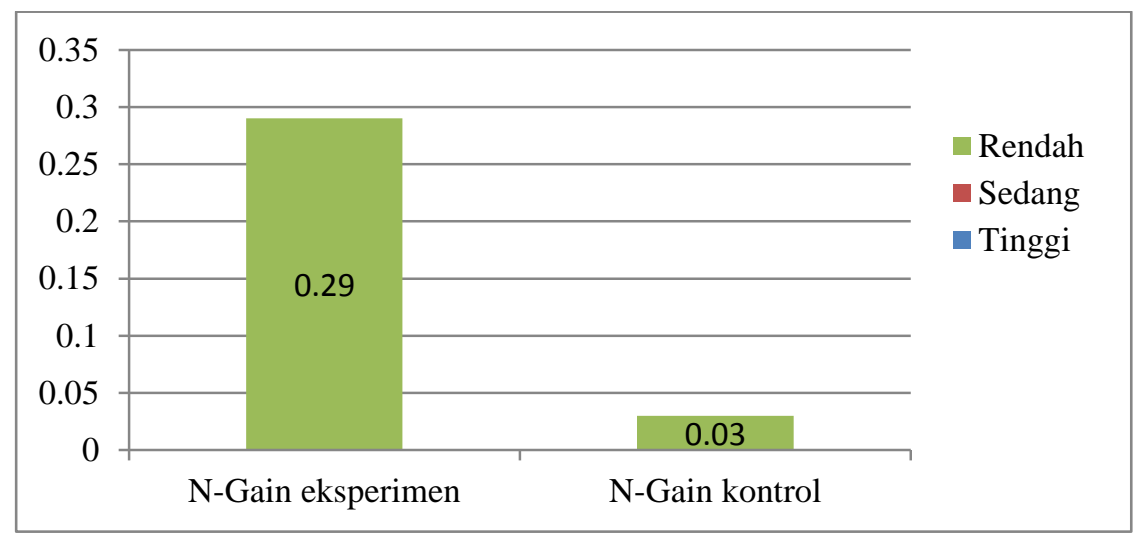

Gambar 1. Perbandingan Rata-rata N-GainSikap Entrepreneurship Kelas Eksperimen dan Kelas Kontrol

Nilai uji signifikansi independent sample T-test adalah 0, berarti $\mathrm{H}_{0}$ ditolak karena lebih kecil dari 0,05 dan $\mathrm{H}_{\mathrm{a}}$ diterima. Artinya terdapat perbedaan peningkatan sikap entrepreneurship siswa pada kelas kontrol dan eksperimen kompetensi keahlian teknik sepeda motor SMK Negeri 1 Majalengka.

\section{PEMBAHASAN}

Penelitian ini dilakukan pada siswa SMK Negeri 1 Majalengka tahun ajaran 2012/2013, dimana jumlah responden dalam penelitian ini adalah sebanyak 67 siswa kompetensi keahlian teknik sepeda motor. Jumlah tersebut terbagi dalam dua kelompok, 34 siswa berada pada kelas eksperimen dan 33 siswa berada pada kelas kontrol. Variabel penelitian yang telah ditentukan yaitu penerapan model pembelajaran TF-6M dan sikap entrepreneurship siswa kompetensi keahlian teknik sepeda motor. Pembahasan penelitian ini memberikan gambaran hasil penelitian secara terperinci, berdasarkan pada teori-teori maupun konsep-konsep yang relevan, dimana penelitian ini menggunakan metode eksperimen semu atau disebut kuasi eksperimen. 
Pelaksanaan penelitian ini menggunakan instrumen angket untuk mengetahui sikap entrepreneurship siswa, dimana instrumen ini terdiri dari 61 item soal yang terdiri dari beberapa aspek sikap entrepreneurship. Penelitian yang dilakukan di kelas XI teknik sepeda motor SMK Negeri 1 Majalengka ini, bermaksud untuk membuktikan teori bahwa model pembelajaran yang digunakan sesuai tujuan pembelajaran dapat mempengaruhi sikap siswa. Pelaksanaan model pembelajaran TF-6M yang dilakukan mengacu pada pelaksanaan industri jasa otomotif perbaikan sepeda motor, dimana siswa merasakan bagaimana industri jasa otomotif yang dikombinasikan dengan proses belajar mengajar. Pelaksanaan penelitian ini bermaksud untuk merangsang munculnya dorongan faktor internal dari dalam diri siswa yang berupa motivasi berprestasi, berorientasi ke depan, kepemimpinan wirausaha, jaringan usaha, serta responsif dan kreatif menghadapi perubahan. Sehingga pengaruh tersebut dapat meningkatkan sikap enterpreneurship siswa kelas XI kompetensi keahlian sepeda motor.

Berdasarkan hasil dari postest kedua kelas, melalui perhitungan persentase ketercapaian skor setelah postest dilakukan, rata-rata persentase ketercapaian skor dari kelas eksperimen adalah sebesar 81,53\%, dan untuk kelas kontrol adalah 74,14\%, hal ini menunjukkan bahwa adanya peningkatan sikap entrepreneurship siswa kelas eksperimen setelah diberikan perlakuan model pembelajaran TF-6M. Kelas eksperimen mendapatkan jauh lebih banyak pengalaman untuk aktif dalam proses belajar mengajar. Melihat dari hasil persentase ketercapaian skor postest, terlihat peningkatan sikap entrepreneurship siswa kelas eksperimen pada masing-masing indikator sikap entrepreneurship. Berdasarkan landasan teori mengenai model pembelajaran TF6M. Ketika pelaksanaan model pembelajaran ini, proses belajar mengajar yang berbeda membuat siswa merasakan pengalaman yang berbeda pula. Siswa mendapatkan pelajaran yang sangat berharga yang tidak pernah mereka dapatkan dengan model pembelajaran yang biasa dilakukan di sekolah. Pembelajaran yang biasa dilakukan di sekolah membuat siswa kurang aktif dan produktif untuk selalu belajar kompetensi yang harus siswa miliki (Rusman, 2012).

Hasil yang diperoleh dari penelitian menunjukkan bahwa motivasi berprestasi dalam berwirausaha di kalangan siswa kelas eksperimen naik sebesar 7,5\%, dengan nilai $\mathrm{N}$-Gain 0,30 yang berada pada kategori sedang. Peningkatan sikap motivasi berprestasi ini dikarenakan pada model pembelajaran TF-6M siswa memperoleh banyak pengalaman yang baik untuk memupuk sikap pekerja keras, tidak mudah menyerah, memiliki semangat, dan memiliki komitmen. Hal ini ditunjukkan dengan proses pembelajaran pada beberapa langkah kerja di model pembelajaran TF- 
6M. Langkah kerja mengerjakan pesanan, siswa mengerjakan pesanan dengan bekerja keras agar pesanan yang dikerjakan selesai dengan benar dan tepat waktu, dan tentunya pada saat mengerjakan pesanan siswa juga terpacu untuk tidak mudah menyerah dan memiliki semangat yang baik. Sikap memiliki komitmen juga ditunjukkan pada saat langkah menyatakan kesiapan mengerjakan pesanan, siswa mempunyai komitmen kepada konsumen untuk dapat mengerjakan pesanan dengan baik dan tepat waktu. Hal ini senada dengan pendapat Hendro (2011:186) yang mengatakan bahwa komitmen wirausaha adalah berorientasi pada mutu kerja yang prima, bukan asal asalan. Konsumen tidak akan membeli produk atau jasa yang asal-asalan mutunya. Suatu hal yang dipegang oleh konsumen adalah janji terhadap mutu kerja seorang wirausaha.

Berdasarkan hasil yang diperoleh dari penelitian ini, menunjukkan bahwa sikap berorientasi ke depan siswa kelas eksperimen mengalami peningkatan sebesar 5,82 \%, dengan nilai $\mathrm{N}$-Gain sebesar 0,23 yang masuk dalam kategori rendah. Walaupun peningkatan dalam kategori rendah. Nilai peningkatan untuk kelas eksperimen jauh lebih besar daripada kelas kontrol yang memakai model pembelajaran biasa. Langkah kerja TF-6M memacu siswa untuk berusaha berfikir positif terhadap setiap pesanan yang dikerjakan, siswa yakin dapat mengerjakan pesanan dengan baik sebelum mengerjakannya. Proses mengerjakan pesanan juga memupuk siswa untuk mengerjakan pesanan dengan sedetail mungkin, sehingga setiap pemeriksaan komponen kendaraan tidak ada yang terlewatkan satupun. Ketika siklus yang pertama, kemampuan siswa dalam mengerjakan pesanan masih banyak kesalahan yang terjadi, tetapi karena siswa mau instropeksi diri dan ingin maju, pada siklus berikutnya siswa terlihat jauh lebih bagus mengerjakan pesanan daripada siklus sebelumnya. Hal ini senada dengan pendapat Kartib dan Yuyus (2010:118) yang mengatakan bahwa, dalam kewirausahaan orang yang berfikir positif adalah orang yang mengisi pikirannya dengan tujuan yang baik, keinginan untuk maju, memperbaiki kesalahan yang pernah terjadi, bekerja sama dan saling membantu.

Penelitian ini juga menunjukkan bahwa sikap kepemimpinan wirausaha siswa kelas eksperimen mengalami peningkatan sebesar 6,08\%, dengan nilai $N$-Gain sebesar 0,25 yang masuk dalam kategori rendah. Ditunjukkan dari beberapa pengalaman siswa yang diperoleh melalui model pembelajaran TF-6M ini. Setiap langkah pada model pembelajaran ini siswa dituntut untuk mempunyai sikap kepemimpinan. Tanpa rasa keberanian untuk bertindak, berani mengambil resiko, kepercayaan diri, siswa tidak akan berani untuk menerima konsumen, menyatakan kesiapan mengerjakan pesanan, menganalisa pesanan, mengerjakan pesanan, 
melakukan quality control, serta menyerahkan pesanan ke konsumen. Berani mengambil resiko wirausahawan adalah ketika menetapkan keputusan telah memahami secara sadar resiko yang bakal dihadapi (Winarno, 2011). Kemudian kemungkinan resiko itu diperkecil, dalam hal ini penerapan inovasi merupakan usaha yang kreatif untuk memperkecil kemungkinan terjadinya resiko. Setelah dilakukan perlakuan model pembelajaran, hasil yang diperoleh penelitian menunjukkan bahwa sikap jaringan usaha pada kelas eksperimen meningkat sebesar 9,49\%, dengan nilai $N$-Gain sebesar 0,36 yang termasuk dalam kategori sedang

Sikap responsif dan kreatif menghadapi perubahan juga mengalami peningkatan sebesar 9,14\%, dengan nilai $\mathrm{N}$-Gain sebesar 0,32 yang masuk dalam kategori sedang. Data yang sudah dipaparkan membuktikan bahwa setiap indikator sikap enterpreneur kelas eksperimen mempunyai peningkatan yang lebih besar daripada peningkatan setiap indikator sikap enterpreneur pada kelas kontrol. Faktor pembentukan sikap yang menyatakan bahwa, untuk dapat menjadi dasar pembentukan sikap, pengalaman pribadi harus meninggalkan kesan yang kuat. Karena itu, sikap akan lebih mudah terbentuk apabila pengalaman pribadi tersebut melibatkan faktor emosional, situasi yang melibatkan emosi dan penghayatan akan pengalaman akan lebih mendalam dan lebih lama membekas. Melalui model TF-6M terbukti bahwa model pembelajaran ini mampu memberikan pengalaman pribadi yang positif penuh penghayatan yang membuat pengalaman-pengalaman ini membekas baik dan membentuk sikap yang baik bagi siswa.

Model pembelajaran merupakan salah satu faktor yang dapat mempengaruhi terbentuknya sikap siswa. Sikap entrepreneurship adalah salah satu sikap yang perlu dibentuk melalui proses pembelajaran SMK, supaya tujuan SMK untuk menyiapkan siswa yang siap kerja dan mampu berwirausaha dapat terwujud. Melalui hasil penelitian ini membuktikan bahwa model TF-6M dapat meningkatkan sikap entrepreneurship siswa kompetensi teknik sepeda motor SMK Negeri 1 Majalengka, walaupun jika dilihat dari hasil rata-rata $N$-Gain yang didapat, peningkatannya masih dalam kategori rendah. Pelaksanaan penelitian ini sudah sesuai dengan prosedur penelitian dan kajian teori yang ada. Akan tetapi, peningkatan yang masih dalam kategori rendah ini dikarenakan dalam memupuk sikap seseorang sangatlah tidak mudah. Sikap terbentuk dengan adanya pengalaman hidup secara berkelangsungan. Penelitian ini juga hanya memberikan pengalaman mengenai industri sebanyak lima kali proses pembelajaran. Sarana yang dimiliki 
oleh sekolah juga kurang memadai, dengan hanya mempunyai bike lift sebanyak 3 buah, membuat proses pembelajaran TF-6M kurang maksimal.

Adanya perbedaan peningkatan sikap entrepreneurship antar kedua kelas dibuktikan dengan pengujian hipotesis yang membuktikan bahwa terjadi perbedaan peningkatan sikap entrepreneurship siswa yang menggunakan model pembelajaran TF-6M dan siswa yang menggunakan model pembelajaran yang biasa dilakukan di sekolah. Model pembelajaran TF-6M dikembangkan mengacu pada beberapa konsep model dan teori pembelajaran, yaitu konstruktivisme, work based learning, production based learning, life skill dan teaching factory (Hidayat, 2010). Melalui gabungan teori-teori pembelajaran tersebut pembelajaran TF-6M siswa dapat meningkatkan sikap entrepreneurship, karena pada proses pembelajaran TF-6M dalam bidang jasa, pengalaman yang didapatkan siswa sama seperti halnya industri wirausaha jasa otomotif. Pembentukan sikap entrepreneurship, adalah salah satu proses pembentukan sikap entrepreneurship dengan proses jalur rekayasa, yaitu proses secara sistematik baik melalui proses pendidikan, pelatihan yang terstruktur maupun dengan proses akuisasi pengalaman kerja dan teknis dengan ikut aktif berada dan berbuat serta beraktifitas sebagaimana layaknya para wirausaha di tempat kerja.

\section{KESIMPULAN}

Berdasarkan tujuan yang ingin dicapai dalam penelitian ini, maka diperoleh kesimpulan yang dapat diambil. Berdasarkan hasil analisis data, terdapat perbedaan peningkatan sikap enterpreneurship siswa yang menggunakan model pembelajaran Teaching Factory 6 Langkah dengan model pembelajaran yang biasa dilakukan di sekolah. Hasil penelitian ini membuktikan bahwa model pembelajaran Teaching Factory 6 dapat meningkatkan sikap entrepreneurship siswa kompetensi keahlian teknik sepeda motor di SMK Negeri 1 Majalengka, walaupun secara kriteria rata-rata $\mathrm{N}$-Gain peningkatan tersebut masih dalam kategori rendah.

\section{DAFTAR PUSTAKA}

Hendro. (2011). Dasar-Dasar Kewirausahaan. Paduan bagi Mahasiswa untuk Mengenal, Memahami daan Memasuki Dunia Bisnis. Jakarta: Erlangga. 
Hidayat, D. (2010). Pengembangan Model Pembelajaran Teaching Factory 6 Langkah (Model TF-6M) Untuk Meningkatkan Kompetensi Siswa Dalam Mata Diklat Mata Pelajaran Produktif Sekolah Menengah Kejuruan. Disertasi Doktor pada Program Studi Pengembangan Kurikulum SPs UPI. Bandung: Tidak Diterbitkan.

Kartib dan Yuyus, (2010). Kewirausahaan. Pendekatan Karakteristik Wirausahawan Sukses.Jakarta: Kencana Predana media group

Meredith, G. et al. (1992). Kewirausahaan Teori dan Praktek. Jakarta: PT Pustaka Binaman Pressindo.

Rusman. (2012). Model-Model Pembelajaran. Jakarta: PT Raja Grafindo Persada.

Suryana, Y dan Bayu, K. (2010). Kewirausahaan Pendekatan Karakteristik Wirausahawan Sukses. Jakarta: Kencana Predana Media Group.

Winarno. (2011). Pengembangan Sikap Enterpreneurship dan Intrapreneurship. Jakarta: PT Indesk. 